Volume-V, Issue-02, July-December, 2010

\title{
Ceramic Industry of Bangladesh: A Perspective from Porter's Five Forces Model
}

\author{
Nusrat Jahan ${ }^{1}$
}

\begin{abstract}
Michael Porter's Five Forces Model is one of the famous tools for analyzing an industry's environment. According to this model, a company can achieve its existence and success in an industry only if it can overcome and sustain the competitive forces of the market within which it operates. Ceramic industry of Bangladesh is a booming sector and the growth potential of both domestic and local market indicates it may become one of the big foreign exchange earners for the country. Therefore, analyzing the industry environment of ceramic sector is of great concern to strategist since defending against the competitive forces of the marketplace and shaping them in a company's favor are crucial to strategy formation. To address this issue, this paper analyzes the industry environment (competitive environment) of ceramic sector of Bangladesh by using Porter's Five forces model. The analysis of five forces indicates that the collective impact of the competitive forces is moderate to weak; hence, the ceramic industry of Bangladesh is considered to be competitively attractive in the sense that industry members can reasonably expect to earn decent profits and a nice return on investment.
\end{abstract}

Keywords: Ceramic Industry, Five forces model, Competitiveness, Attractiveness.

\subsection{INTRODUCTION}

All companies operate in a "macro-environment" shaped by influences emanating from the economy at large as well as population demographics; societal values and lifestyles, government legislation and regulation, technological factors, closer to home, the industry and the competitive arena in which the company operates. The factors and forces in a company's macro-environment typically affect the company's immediate industry and competitive environment, including competitive pressures, actions of rival firms, buyer behavior, supplier related considerations and so on. Insightful diagnosis of a company's immediate and competitive environment is a prerequisite to succeed in crafting a strategy that is an

1 Lecturer, School of Business, Independent University Bangladesh, Chittagong, Bangladesh. 
excellent fit with the company's situation and the most powerful tool for such diagnosis is "Porter's Five Forces Model" (Porter 1980, Thompson et al. 2007). This framework has been used in this paper to diagnose the immediate and competitive environment of ceramic sector. The growth potential of both domestic and export market indicates that ceramic industry has every potential to become a big foreign exchange earner for the country in the near future. Traditionally known for jute and tea exports, Bangladesh entry into ceramic export market is not that old. But the industry has witnessed a rapid growth since 1991. This sector has already earned a good name in the global market for its quality products with elegant getup and design. Bangladesh exported only US\$1 million worth of ceramic wares in 1991 before recording a staggering 695\% growth in about a decade (Daily Ittefaq 2009). Though the export earning from ceramic sector is growing rapidly, it is no match in comparison to the readymade garment or leather sectors. Ceramic products have a $\$ 20$ billion global market, of which Bangladesh's share is only $0.17 \%$. However, a silent revolution has been taking shape in the country's ceramic sector for the last few years. This industry contributes a lot to the country's overall development by generating direct and indirect employment, attracting foreign investment and exploring new markets in Europe, the USA, the UAE and the Middle East (Khan 2009). Therefore, this paper addresses the need to research on the industry environment of ceramic sector of Bangladesh.

\section{RESEARCH METHODOLOGY}

Porter's Five Forces model is used to analyze the industry environment of ceramic sector. To identify the five forces within which the incumbent's or company's operate in the ceramic industry, information were primarily collected from the secondary sources. These include books, newspaper articles, journal articles, website publications by Export Promotion Bureau and Bangladesh Bank and online articles from different news-based websites.

\section{THE FIVE FORCES MODEL}

An industry can be defined as a group of companies offering products or services that are close substitutes for each other. Close substitutes are products or services that satisfy the same basic consumer needs. It is important to analyze the competitive forces in an industry's environment in order to identify the opportunities and threats confronting a company (Hills and Jones 1998). The competitive forces operating in a company's industry are never the same for one industry to another. The most powerful and widely used tool for systematically diagnosing the principal competitive forces in a market and assessing the strength and importance of each is the 'five forces model of competition'. Michael. E. Porter 
of the Harvard School of Business Administration has developed this model that effectively facilitates industry analysis. This model, depicted in Figure 3.1 (in appendix), holds that the state of competition in an industry is a composite of competitive forces operating in five areas of overall market (Porter 1980, Thompson et al. 2007):

(i) Competitive pressures among rival sellers in the industry;

(ii) Competitive pressures associated with threat of new entrants into the market;

(iii) Competitive pressures coming from the attempts of companies in other industries to win buyers over their own substitute products;

(iv) Competitive pressures coming from supplier bargaining power;

(v) Competitive pressures stemming from buyer bargaining power;

Understanding these competitive forces and their underlying causes reveals the roots of an industry's current profitability while providing a framework for anticipating and influencing competition (and profitability) over time (Porter 2008). Porter argues that the stronger each of these forces is, the more limited is the ability of established companies to raise prices and earn greater return. Within Porter's framework, a strong competitive force can be regarded as a threat since it depresses profits. A weak competitive force can be viewed as an opportunity, for it allows a company to earn greater profits. The strength of these five forces may change through time as industry conditions change profits (Hills and Jones 1998).

\section{PRESENT SCENARIO OF CERAMIC INDUSTRY}

The global ceramic industry is worth of US $\$ 20$ billion. Bangladesh is perfectly positioned to expand rapidly in this sector with its high quality, cost ratio and creative human resource base. Traditionally, ceramic industry is a labor-intensive sector and companies in developed countries experience difficulties in remaining competitive due to rising labor cost and recent global financial crisis. Bangladesh, being a gas rich, low-labor cost economy and having advanced 'bone china' technology, is perfectly positioned to be a strategic partner in production and supply of ceramic goods (Board of Investment, Bangladesh).

The ceramic industry is surprisingly not quite a new one in Bangladesh. It dates back to 1962. People Ceramic Industries Ltd (PCI) pioneered the manufacture of porcelain tableware in Bangladesh (Khandaker and Alamgir 2006). According to Bangladesh Ceramic Ware Manufacturers Association (BCWMA), there are approximately 40 ceramic manufacturers operating in this industry producing tableware, sanitary ware and tiles. A medium scale ceramic plant needs around 
Taka 10 crore (Taka 100 million) in initial investment and the BCWMA sources say the present investment in the country's ceramic industry is roughly about Taka 2,000 crore (Taka 20 billion) and this sector employs some one lakh (0.1 million) workers. Shinepukur, Monno, Bengal Fine, Standard, Peoples and National Ceramic are considered as major players in ceramic tableware market. RAK, Fu Wang, China-Bangla, FARR, Modhumoti, ATI, Sunflower, Great Wall, Dhaka-Sanghai and Mir are considered as major manufacturers of tiles and sanitary wares and their share of market is depicted in Figure 4.1 (in appendix). The total capacity of ceramic tableware manufacturing companies is nearly 24,000 tonnes a year as of 2008, of which an average of 48 percent is exported and the remaining 52 percent is used in the domestic market. Monno and Shinepukur have the highest production capacity of nearly 60,000 pieces a day, followed by Standard ceramics with 40,000 pieces a day. According to a market study, the existing tiles factories produced 374 million square feet of tiles in 2008 and the output is estimated to grow at the rate of 17 percent in 2009 and 2010. Of the total production of 322 million square feet of tiles in 2007, RAK ceramics alone made 74 million square feet followed by ChinaBangla, Fu-wang an Mir, each produced slightly over 30 million square feet of tiles (M. Islam 2010, Khan 2009, Rahman 2009c, 2009e).

Over the years, the ceramic industry in Bangladesh has flourished immensely and has gained recognition throughout the world. Local ceramic ware manufacturing industry is expecting a steady growth with a US $\$ 100$ million return from exports by 2015 as the global market favors more shipment from Bangladesh. The Export Promotion Bureau (EPB) and Bangladesh Bank statistics shown in Figure 4.2 (in appendix), put the total value of export earnings from ceramic ware at $\$ 38.33$ million in the FY $2007-08$, up by $28 \%$ from the previous year and in the last fiscal year, the earnings stood at $\$ 31.70$ million. After a consistent growth in last 15 years, this sector is now in a good position to achieve the target of $\$ 100$ million export earnings (Daily Ittefaq, 2009; Hossain, 2009; Export Promotion Bureau and Bangladesh Bank).

Quality of products has helped Bangladesh to carve a niche in the global market; the manufacturers in this sector are taking risks while diversifying their designs into world-class standards. Furthermore, the natural gas that is used in the kilns of the Bangladesh's ceramic industry does not contain any sulphur and that is why the country's ceramic products look brighter and shiny. The close competitors of Bangladesh are China and India, but they mostly produce traditional items. Moreover, due to recent global financial crisis and rising labor cost, the developed countries are placing more orders to low-cost countries like Bangladesh. The trend of growth rate of this sector since 1991 show that the export market will grow further. To cope with the increased export demand, all major exporters, such as 
Monno Ceramic, Shinepukur Ceramic, and Bengal fine ceramic, have been expanding their plant (Khan 2009).

Though export market of Bangladeshi ceramic industry is growing, the domestic market share of local ceramic wares is shrinking due to widespread import of low-priced foreign goods, mainly from China. As overseas demand is going up, country's major manufacturers are now pumping 80 percent of the production into the international market. Moreover, the local companies export much of the products to the international market, thus creating a demand-supply gap in Bangladesh. Due to this, imports of ceramic products in Bangladesh are increasing very fast parallel to the growth in export. In the year 2008-09, for instance, the country imported finished ceramic products, glass and glass ware products worth of approximately US\$75 million and exported ceramic products worth of US $\$ 31.70$ million (Kakati 2008, Rahim 2005, Export Promotion Bureau and Bangladesh Bank).

Of different ceramic products, ceramic tablewares are exported to about 50 countries including the USA and Canada, tiles to India, Nepal and Bhutan and sanitary ware to the Middle East, especially to the UAE. The industry sells ceramic products worth of Taka 1,000 crore (Taka 10 billion) annually in the domestic market and pays taxes close to Taka 300 crore (Taka 3 billion) and Taka 100 crore (Taka 1 billion) to the utility services, including gas (Khan 2009, Islam 2010).

\section{DETERMINING PORTER'S FIVE COMPETITIVE FORCES OF CERAMIC INDUSTRY}

Industry structure grows out of a set of economic and technical characteristics that determine the strength of each competitive force (Porter 2008). An industry's dominant economic features are defined by such factors as market size and growth rate, number of rivals, scope of competitive rivalry, number of buyers, degree of product differentiation, product innovation, supply or demand conditions, pace of technological change, vertical integration, economies of scale and learning or experience curve effects (Thompson et al. 2007). Porter's model is based on the insight that the competitive strategy of an incumbent or a company should be based on an understanding of industry structure and the way they change (Aliakbari and Tousi). In this section, the industry environment of ceramic sector will analyzed by five recognized competitive forces developed by Michael E. Porter (Porter 1980). This analysis presents a picture of industry's growth situation and its attractiveness. 


\subsection{Competitive Rivalry within the industry}

The ceramic industry of Bangladesh faces stiff competition from foreign sources like Sri Lanka, China and Thailand but the domestic marketplace is yet weakly competitive. Ceramic manufacturers like Monno Ceramic, Shienpukur Ceramic, Standard Ceramic, FARR Ceramic and Bengal Fine ceramic are still leading, especially in the export market, and have been recently expanding their plant to further improve their share of export market. All other ceramic manufacturers are also increasing their production capacity following robust growth in demand for ceramic wares. Due to the global recessionary impact and rising labor cost, the developed countries are placing more orders to low-cost countries for quality ceramic wares; hence, the export demand for Bangladeshi ceramic ware is growing rapidly. Addressing this strong growth, the numbers of competitors, roughly of equal size and competitive capability, are increasing in this industry day by day (Khandaker and Alamgir 2006, Khan).

The competing local manufacturers are also active in making fresh moves to improve their market standing and business performance. For instance, X Ceramics produces ceramic tiles for both interior and exterior usage. According to the management of this company, they are the first to manufacture tiles made of ceramics intended for external use that would be manufactured within the country. Besides, X ceramics is also increasing its production capacity to manufacture $20 \%$ more output than their nearest competitors to gain $25 \%$ of the market share. This company is also coming up with powerful strategies like teaming up with overseas entity to share its technological know-how and to turn its concern into the "first ever European Standard multinational joint venture ceramics manufacturing facility." The strongest competitive pressures come not from outsiders, but also from current industry participants. Great Wall Ceramic Industries Ltd., has announced to produce a high-end product, fine-cut tiles with decorated borders to meet local demand since demand for costly tiles is high. FARR Ceramics Ltd., which went into commercial production in February 2007, already bagged 10\% market share in Bangladeshi ceramics exports and is among the few now showing resilience against global recession. Moreover, the management of FARR Ceramic claims, it is the first Bangladeshi company to enter the export market of Argentina after shoring up its foothold in Europe (Rahman 2009c, 2009f, Bhuiyan 2009, Star Business Report 2009).

However, increment in the number of new plants, capacity development, product development and market expansion by ceramic ware manufacturers of Bangladesh are still low compared to the robust growth in demand both in export and local market. As there still exit ample growth opportunities in this industry, the 
rivalry among the existing companies are still weak, thus making this sector more attractive for the potential entrants.

\subsection{Bargaining Power of Buyers}

Individual consumers of ceramic products in this industry have much bargaining power in negotiating price concession or other favorable terms with seller, hence, the individual buyers mostly pay the seller's posted price. However, it is relatively easy for buyers to switch to comparatively low-priced imported ceramic goods; keeping this in mind, the local manufacturers are aiming for competitive pricing to attract and retain customers.

Ceramic ware manufacturers of Bangladesh have managed to create a solid stand in the international market. So, most ceramic manufacturers, keeping this foreign market success in mind, have turned more towards exports. Bangladesh has got a huge opportunity in ceramic tableware market because of increasing demand from the developed countries where the production cost of ceramic tableware has increased significantly due to an enormous rise in labor cost. Bangladesh's export markets include the UK, the USA, Canada, Spain, Italy, Australia, New Zealand, Norway, Germany, Sweden, Russia, the UAE, Denmark, France, Mexico, Argentina, Turkey, India, Nepal, Bhutan and many other European and Middle East countries (Rahman 2009a).

The bargaining power of these international buyers is reasonably strong enough to negotiate for price concession and favorable terms since they can always switch to low-priced suppliers of ceramic wares from China, Sri Lanka, Thailand and Malaysia. But due to increased production cost, these countries are also failing to offer competitive prices and losing their share in the international market. Thus, more international buyers are moving towards Bangladesh as it has cost competitiveness in terms of gas supply, cheap labor cost, skilled labor and also has competitive advantage of possessing "bone china" technology (Khan 2009). As the number of buyers, both in local and international market, is growing, the bargaining power of buyers is weakening.

\subsection{Bargaining Power of Suppliers}

Bangladesh needs to import $100 \%$ raw materials for producing ceramic wares. The raw materials account for 35-40 percent of the total production cost of the ceramic products. The raw materials of ceramic wares include China clay, ball clay, fire clay, feldspar, quarters plaster of Paris, aluminum oxide, aluminum hydro oxide, zinc oxide, coloring items and liquid gold. These raw materials and 
machineries are imported from mainly India, China, Rumania, Indonesia, Italy and Germany. The Mymensingh clay could be used for producing tiles, but in 2007 the government put an embargo on cutting hills which stopped the ceramic manufacturers from procuring raw materials from the Mymensingh hills. Since in Bangladesh, there is a shortage of raw materials, equipment and machineries for ceramic industry, it gives the supplier more leverage in bargaining the price. But the supplier base of ceramic sector is moderately large enough to weaken the supplier power. However, some of the suppliers like India are also showing interest to integrate into the ceramic industry of Bangladesh and perhaps could become a powerful rival (Chowdhury 2004, Islam 2010, Khan 2009).

\subsection{Threat of New Entrants}

Bangladesh has certain competitive advantages in the international market in terms of availability of gas, cheap labor and the generalized system of preferences (GSP) that allows Bangladesh to have duty-free exports to Europe and there is no quota restriction either on the export. Considering this sector's potentiality for investment, ceramic industry has always allured both local and foreign investors. Since domestic and export demand for ceramic products are rising rapidly, widening the gap between demand and supply, the new entrants can easily expect to earn attractive profit by capturing the untapped demand (Rahman 2009d, 2009e). As the construction industry including residences, shopping malls and others is growing so fast, the ceramic tiles business is becoming one of the booming and prospective sectors with a staggering annual growth rate of 20 percent, as shown in Figure 5.1 (in appendix).

Demand for ceramic tablewares has also increased significantly in Bangladesh with a continuous rise in use among middle income groups in the past decade. Another reason for this increased demand can be attributed to the sky-rocketing of the price of gold. Due to this may people have turned away from the traditional practice of presenting jewellery at wedding ceremonies and have resorted to the next best option, ceramic tableware.

The export of ceramic products registered an average growth of 20 percent during the last one decade and the domestic sales of ceramic products account for approximately Taka 1,000 crore (Taka 10 billion) annually. Hence, more players are joining this business like Dulal Brothers Ltd, X ceramics and Peragon Ceramic Industries Ltd, etc. Several other ceramic ware manufacturing companies including Akij Group, Padma Ceramics Khaled corporations and Tamanna are in the pipeline to enter this sector by 2011. According to Bangladesh Ceramic Wares Manufactures Association (BCWMA), a medium scale ceramic plant needs around Taka 10 crore (Taka 100 million) in initial investment and in addition to the existing factories, five 
or six new ceramic factories would be set up in the country with an investment of around Taka 3,000 crore (Taka 30 billion), which will generate employment for around 500,000 (0.5 million) workers. Besides, the importers who used to import low-cost Chinese goods are now coming up to set up manufacturing units of their own. According to BCWMA, this transformation has resulted as the government increased the supplementary duty on imports of tiles and sanitary ware to 45 percent (Islam 2010, Rahman 2009e).

The pool of new entry into the ceramic industry of Bangladesh indicates this sector has low entry barriers as the government regulations are supportive for new entrants. However, the number of new entrants and their capacity development is low compared to the growth in domestic and export demand. Hence, the competitive threat of potential entry is not strong enough to place significant competitive pressure on the existing manufacturers.

\subsection{Threat of Substitute Products}

The ceramic industry is already in fierce competition with low-priced sanitary ware, tiles and table wares, mostly imported from China. Besides, this sector is also facing strong competitive pressure from firms in other industries offering substitute products. The demand for low-priced, attractive and convenient substitutes of ceramic tableware such as melamine wares, aluminum wares, steel kitchen wares, glass wares and plastic wares are raising and the local manufacturer of these products are also drawing significant profits from the thriving domestic market for crockery. In recent years, large scale manufacturers have entered the crockery market, with their brands competing strongly with both local ceramics products and foreign products of their same kind. Some local manufacturers are even producing world-class plastic goods, spending a large amount on TV commercials and selling thousands of pieces every month. Companies like Bangladesh Melamine, Sharif Melamine, RFL, BRB, and GAZI are contributing greatly to this thriving crockery market by creating demand for new products. As the import of crockery has increased fourfold in the past decade, the local large manufacturers of these substitute products are also expanding their existing capacities with concentration on new product lines to attract more customers (Islam 2010). Moreover, the history of tiles business is not very old in Bangladesh; still mosaic is popularly used in many urban and sub-urban households. Other substitutes of tiles include wooden flooring or tiles, bamboo flooring, ply board, marble stones and other artificial stones for both interior and exterior usage. Hence, the availability and low cost of substitutes is exerting moderately competitive pressure on the existing companies of ceramic industry. 


\section{RESULTS OF INDUSTRY ENVIRONMENT ANALYSIS}

Understanding industry structure is of great concern to strategist since defending against the competitive forces and shaping them in a company's favor are crucial to strategy. Besides, it is also essential for effective strategic positioning of a company (Porter 2008). Based on the information derived from five forces analysis, the result is summarized in Table 6.1(in appendix). This analysis will help an incumbent or a company to decide how to influence or to exploit particular characteristics of the ceramic industry. The result shown in Table 6.1 indicates that the industry environment of ceramic sector is weak to moderate competitive and offers ample growth opportunities for both its incumbents and new entrants. As the collective impact of the five competitive forces is moderate to weak, the ceramic industry is considered to be competitively attractive in the sense that industry members can reasonably expect to earn decent profits and a nice return on investment. Therefore, to sustain in this industry, the incumbents or existing companies should match strategy to prevailing competitive conditions of the marketplace. Their strategies should include actions such as continuous product development, quality improvement and offering ranges of prices to satisfy all segments of the domestic and export market.

\section{PROBLEMS ENCOUNTERED BY CERAMIC INDUSTRY}

The problems that the ceramic sector is facing in Bangladesh are as follows:

- The industry suffers due to irregular power and gas supply. The ceramic tableware factory needs to maintain round the clock 380-degree temperature. When power voltage or gas pressure is low such temperature reduces; when the temperature falls, it takes at least 12 hours to bring it back to previous level, causing a huge loss. A low heat in any plant causes fault to color and quality. According to the industry sources, to harness power during the shortfall period they used diesel-run generators, but due to high oil prices it was very expensive. For running such high cost generators, the production cost of ceramic goods rises as well (Khan 2009).

- Ceramic manufacturers pay high tariff on gas compared to other sectors. Presently, average gas tariff is Taka 2/cubic metre for fertilizer factories, Taka 5.13/cubic metre for ceramics factories and Taka 3.5/cubic metre for gas-based power plants (Khan 2005).

- The industry faces high import duty on certain ceramic raw materials from 7.5 percent to 15 percent. Besides, this sector pays high Value Added Tax (VAT) of 15 percent on produced goods (Kakati 2008). 
- This sector also faces difficulty in getting health certificate from Bangladesh Standard Testing Institution (BSTI), which is required by many international buyers, especially in European market. According to industry sources, the existing complex pre-shipment procedure (PSI) delays the process of export and involves additional expenditure to increase production cost (New Age 2009).

- No government support through lower interest rate. Industry people urge the government to fix one digit interest rate on loan and extended it to the ceramic sector.

- In Bangladesh there is shortage of raw materials for ceramic goods and the manufacturers are $100 \%$ dependent on import of raw materials from overseas. Besides, close competitors like China and India have their own raw materials. Hence, the government should take steps to find deposits of superior quality clay for ceramic in the coalmine region of north Bengal (Khan 2009).

- This industry lacks high level manufacturing and industrial engineering techniques, required machinery and equipment and international standard laboratory for testing and quality control. Besides, this sector is in need of research and development effort to economies on energy cost as well as appropriate and adequate training programs to develop pull of skilled labor.

- China gives 22.5 percent incentives to its ceramic exporters, Bangladesh gives nothing. According to industry sources, the government should promote this sector with various incentives as the value addition of this sector is about 65 percent. The industry requires fiscal support from government to give this sector an extra push to capture part of a potential global market along with meeting local demand (Rahman 2009f, Daily Ittefaq 2009).

- The local ceramic tableware manufacturers have become the victim of the 2008 financial crisis. The aggregate export earnings came down to US $\$ 31.70$ million from US\$38.33 million during the fiscal year 2008-09. According to Export Promotion Bureau (EPB), shown in Figure 7.1 (in appendix), Bangladesh exported ceramic tableware worth of Taka 24.5 crore (Taka 245 million) in September 2008, which came down to Taka 21 crore (Taka 210 million) in October and Taka 16.6 crore (Taka 166 million) in November 2008 (Rahman 2009a, Export Promotion Bureau, Bangladesh Bank). 


\section{FUTURE OUTLOOK}

The ceramic industry of Bangladesh could become a basic building block for the country's construction and housing sector; however, this sector is already contributing to the country's economic progress through export earnings, foreign currency savings and generating employment. The industry people say this is possible provided the government supports this sector with due diligence. The government has promised to extend all sorts of cooperation to make Bangladesh the hub of ceramic goods production in the world. Bangladesh government has already drawn a policy to prevent the import of low quality ceramic products having health hazard ingredients. To discourage import of tiles and sanitary ware items, supplementary duty on imports has already increased to 45 percent in place of existing 20 percent. Besides, the government has also promised uninterrupted power and gas supply for this sector. Moreover, the certain provisions of the Budget 200910, for instance, providing accommodation for all by 2021, would have positive impact on the ceramic industry as well (New Age 2009, Islam 2010).

If the ceramic industry of Bangladesh can overcome the stated limitations, it has every potential to grow and become a big foreign exchange earner for the country with its dazzling products in the era of globalization. 


\section{REFERENCES}

Aliakbari, F. and H. S. Tousi. n.d. Using Porters Five Forces Model for Analyzing the Environment of Environmental Media-owner Companies. (Case Study: An Ad promotion company). Retrieved from http://icbm.bangkok.googlepages.com/78. Fatemeh. Aliakbari. AR. pdf.

Bangladesh Bank. http://www.bangladesh-bank.org.

Bhuiyan. M. M.2009, July 5. X-Ceramics to Go for Trial Production by end of Next Month. The Financial Express.

Board of Investment "Bangladesh. Ceramics Sector Highlights." Retrieved from http://www.boi.gov.bd/key-sectors/ceramics.

Daily Ittefaq .2009 November 7. "Ceramic Wares Export Potential."

Bangladesh News Online.2008, September 17. "Ceramic Sector Eyes \$100m Export." Retrieved from http://www.independent-bangladesh.com/ 200809169876/business/ ceramics-sector-eyes-\$100m-export.html.

Chowdhury, T. A. ed. 2004. "Budget proposal for 2004-05 Fiscal, Ceramic Industry for Minimum Duty Slab on Raw Materials." In News from Bangladesh: Daily News Monitoring Service. Retrieved from http://www.bangladesh-web.com/aboutus.php.

Chowdhury, T. A. ed. 2004. June 24). "Budget Worries Local Ceramic Industry". In News from Bangladesh: Daily News Monitoring Service. Retrieved from http://www.bangladesh-web.com/aboutus.php.

Export Promotion Bureau. Retrieved from http://www.epb.gov.bd/

The Financial Express. 2007 June 27. "Some Budgetary Measures to Hit Ceramic Industry."

Hossain, S. 2009, August 3. “Ceramic Ware Exporters Aim Sturdy Business”. Daily New Age. Dhaka.

Hill, C.W. and G. R. Jones. 1998. Strategic Management: An Integrated Approach. $4^{\text {th }}$ ed. Boston: Houghton Mifflin Company. 
Islam, K. A. 2010, March 5. "Changing Lifestyle Gives Crockery Industry a Boost.” New Age.

Islam, M. S.2010, April 16. "Ceramic Importers Turn Manufacturers.” The Independent.

Khandaker, N. and R.Alamgir. 2006, August 1. "Not Just Your Average Cup of Tea." The Daily Star.

Khan, A. A. n.d. "Ceramic Industry in Bangladesh." Retrieved from http://www.bangladeshinfo.com/business/others01.php.

Khan, K. 2005. September 17. "Ceramic Industry Seek Policy Support.” The Daily Star.

Khan, K. 2006. July 15. "12.11pc Fall In Ceramic Tableware Export in 10 Months of FY06.” The Daily Star.

Kakati, W. 2008. July 15. "Ceramic Sector in Bangladesh: Opportunities Unbound". Retrieved from http://smetimes.tradeindia.com/smetimes/indepth/2008/Jul/15/ceramic-sector-in-bangladesh-opportunities-unbound.html.

Khan, S. 2009. February 9. "Ceramic Industry on Road to a Modest Growth.” The Financial Express.

Porter, M. E. 1980. Competitive Strategy: Techniques for Analyzing Industries and Competitors. New York: The Free Press.

Porter, M. E. 2008. "The Five Forces that Shape Strategy". Harvard Business Review.

Rahim, M.A. 2005, February 22. "Ceramic Makers Eye \$100m Annual Export by 2008." The Daily Star.

Rahman, S. 2009a, January 29. "Recession Creeps into Ceramic Tableware. The Daily Star.

Rahman, S. 2009b, March 5. "Six Firms Eye Tiles Market." The Daily Star.

Rahman, S. 2009c, July 7. "Local Ceramics Maker Rides out Global Recession." The Daily Star.

Rahman, S. 2009d, August 31. "Ceramics Brace for High Demand." The Daily Star.

Rahman, S. 2009e, November 7. "Tiles Market Heats up.” The Daily Star.

Rahman, S. 2009f, December 10. "FARR Ceramics Sets Foot in Argentina." The Daily Star.

Rahman, M. A. 2005, February 22. "Ceramic Makers Eye \$100m Annual Export by 2008." The Daily Star.

Star Business Report. 2009, November 18. "Great Wall to Unveil New Designs.” The Daily Star.

Thompson et al. 2007. Crafting and Executing Strategy: The Quest for Comparative Advantage. $15^{\text {th }}$ ed. Boston: McGraw-Hill/Irwin. 


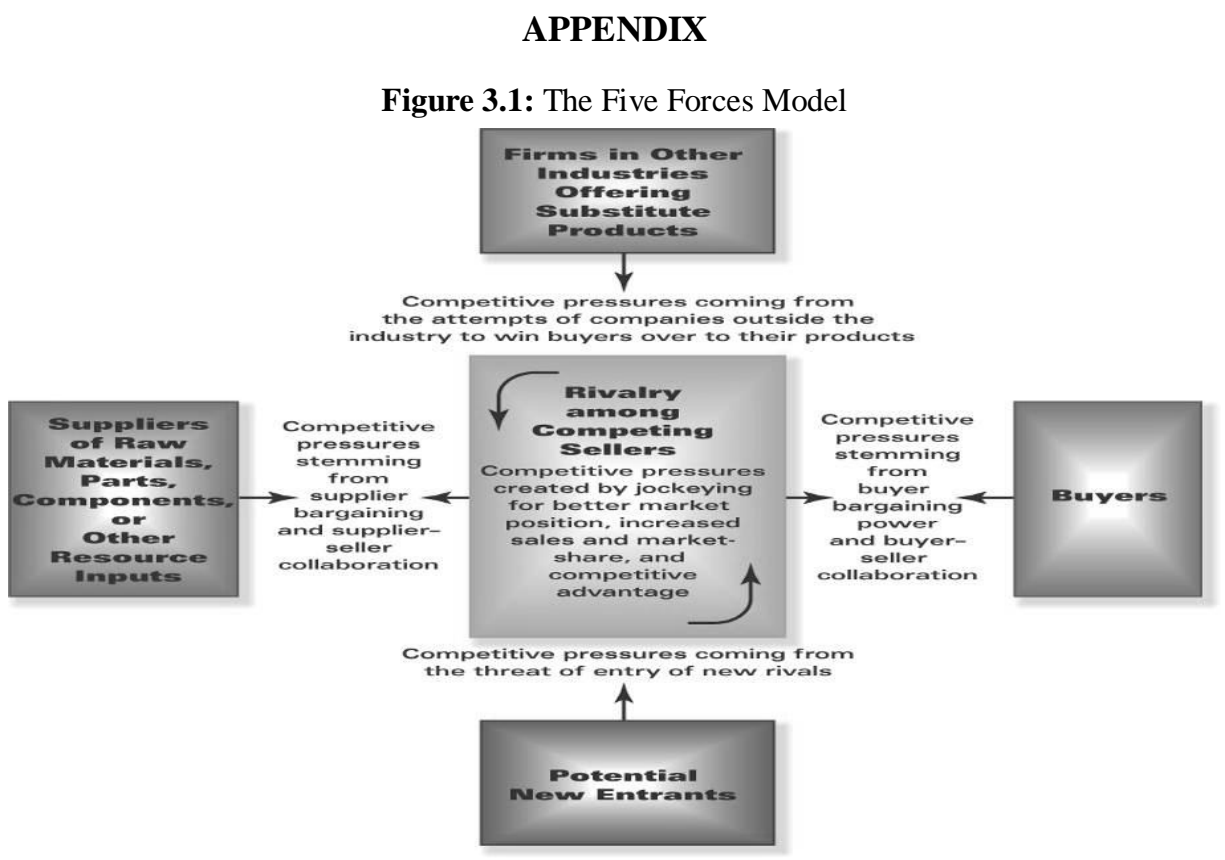

Source: Thompson et al. (2007)

Figure 4.1: Market Share of Ceramic Tiles Manufacturing Companies (in percentage)

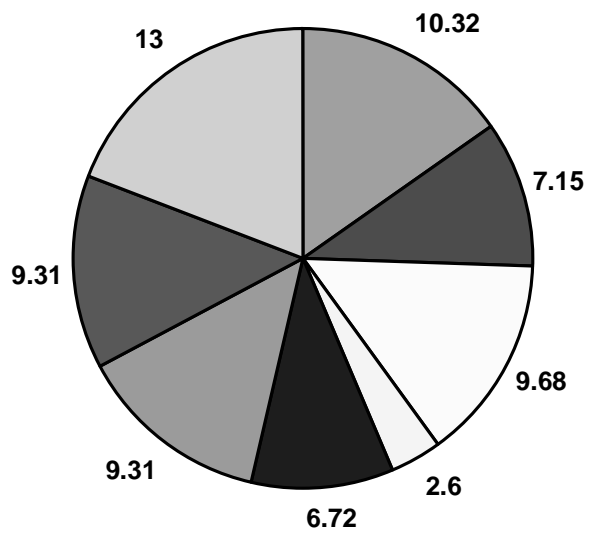

$\square$ China-Bangla

$\square$ Dhaka-Shanghai

$\square$ Fu-wnag

$\square$ Modhumoti

$\square$ Sunpowe

$\square$ Greatwall

$\square$ Mir

$\square$ Imported Goods

Source: The Daily Star, March 5, 2009. 
Figure 4.2: Export Earnings of Ceramic Industry

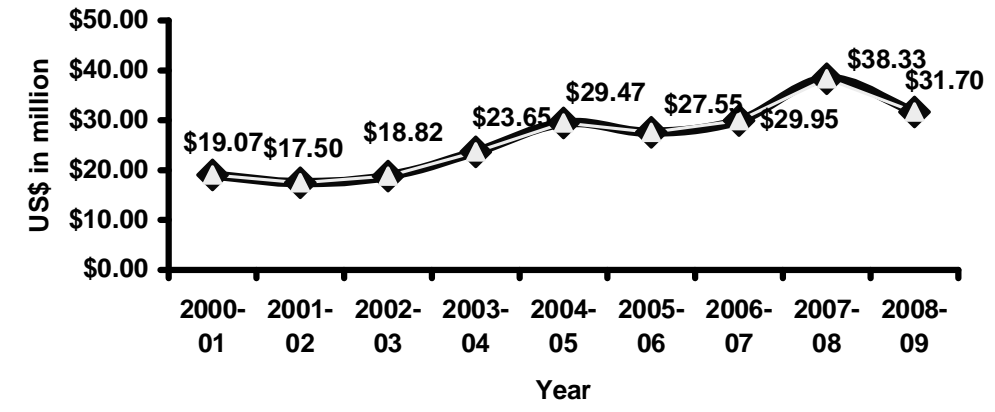

Source: Export Promotion Bureau \& Bangladesh Bank

Figure 5.1: Ceramic Tiles: Annual Growth Trend

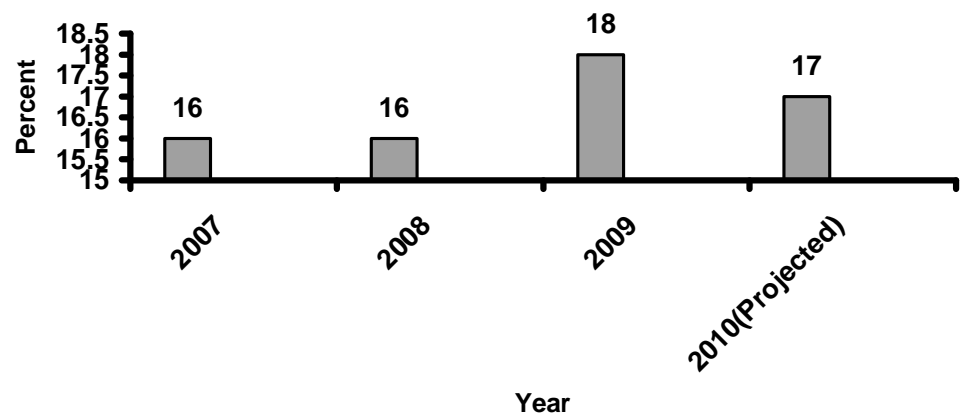

Source: The Daily Star, October 29, 2009 
TABLE 6.1

\section{SUMMARY RESULTS OF CERAMIC INDUSTRY ENVIRONMENT ANALYSIS}

\begin{tabular}{|c|c|c|}
\hline Parameter Competitive Rivalry within the industry & Condition & Effect \\
\hline Primary investment & High & Rivalry $\downarrow$ \\
\hline Market growth: Export & High & Rivalry $\downarrow$ \\
\hline Market growth: Domestic & High & Rivalry $\downarrow$ \\
\hline Probability of competing rivals making fresh moves & Medium & Rivalry $\uparrow$ \\
\hline Existing product diversity / differentiation & Medium & Rivalry $\uparrow$ \\
\hline Possibility of production capacity development by competitors & Medium & Rivalry $\uparrow$ \\
\hline \multicolumn{3}{|l|}{ Bargaining Power of Buyers } \\
\hline Number of potential customers & High & Buyer Power $\downarrow$ \\
\hline Number of actual customers & Medium & Buyer Power $\downarrow$ \\
\hline Imposed cost for switching to an alternative product & Low & Buyer Power $\uparrow$ \\
\hline $\begin{array}{l}\text { Probability of potential customers using another } \\
\text { company's product }\end{array}$ & High & Buyer Power $\uparrow$ \\
\hline Company's financial dependency on selling to customers & High & Buyer Power $\uparrow$ \\
\hline \multicolumn{3}{|l|}{ Bargaining Power of Suppliers } \\
\hline Number of key suppliers & Medium & Supplier Power $\downarrow$ \\
\hline Suppliers ability to bargain for prices and favorable terms & Medium & Supplier Power $\downarrow$ \\
\hline Switching cost from one supplier to another & Medium & Supplier Power $\downarrow$ \\
\hline Suppliers power on product quality & Medium & Supplier Power $\downarrow$ \\
\hline \multicolumn{3}{|l|}{ Threat of Substitutes } \\
\hline Switching cost of end users & Low & $\begin{array}{l}\text { Threat of } \\
\text { substitutes } \uparrow\end{array}$ \\
\hline Availability of substitutes & High & $\begin{array}{l}\text { Threat of } \\
\text { substitutes } \uparrow\end{array}$ \\
\hline Attractiveness of substitutes price & Medium & $\begin{array}{l}\text { Threat of } \\
\text { substitutes } \downarrow\end{array}$ \\
\hline Probability of end-users growing more comfortable with substitutes & Medium & $\begin{array}{l}\text { Threat of } \\
\text { substitutes } \uparrow\end{array}$ \\
\hline \multicolumn{3}{|l|}{ Threat of New Entrants } \\
\hline Pool of new entrants & Medium & $\begin{array}{l}\text { Threat of New } \\
\text { Entry } \uparrow\end{array}$ \\
\hline $\begin{array}{l}\text { New entrants immediate access to industry's required technology and } \\
\text { technical knowledge }\end{array}$ & Low & $\begin{array}{l}\text { Threat of New } \\
\text { Entry } \downarrow\end{array}$ \\
\hline New entrants immediate access to suppliers & Medium & $\begin{array}{l}\text { Threat of New } \\
\text { Entry } \downarrow\end{array}$ \\
\hline Probability that new entrants would earn attractive profits & High & $\begin{array}{l}\text { Threat of New } \\
\text { Entry } \uparrow\end{array}$ \\
\hline Primary Investment & High & $\begin{array}{l}\text { Threat of New } \\
\text { Entry } \downarrow\end{array}$ \\
\hline
\end{tabular}


Figure 7.1: Effect of Global Financial Crisis on Export Earnings

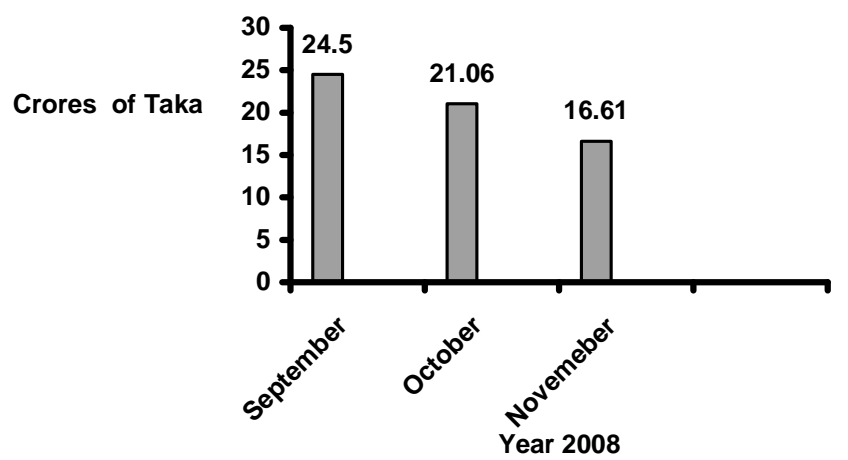

Source: Daily Star, January 29, 2009. 